\title{
Transmission of Global Food Prices to Domestic Prices: Evidence from Sri Lanka
}

\author{
Sivarajasingham Selliah ${ }^{1}$, Shri-Dewi Applanaidu ${ }^{1} \&$ Sallahuddin $\operatorname{Hassan}^{1}$ \\ ${ }^{1}$ School of Economics, Finance and Banking, College of Business, Universiti Utara Malaysia, 06010 Sintok, \\ Kedah, Malaysia \\ Correspondence: Sivarajasingham Selliah, School of Economics, Finance and Banking, College of Business, \\ Universiti Utara Malaysia, 06010 Sintok, Kedah, Malaysia. Tel: 60-111-885-4132. E-mail: ssivaraj@pdn.ac.lk
}

\author{
Received: December 9, 2014 Accepted: January 27, 2015 Online Published: April 30, 2015 \\ doi:10.5539/ass.v11n12p215 URL: http://dx.doi.org/10.5539/ass.v11n12p215
}

\begin{abstract}
Food prices have been increasing sharply since 2003. In the globalized world, the transmission of global food price increases to domestic market determines the decision of economic agents and policy makers of a domestic economy. The recent growth of global food prices affects the welfare of poor consumers and producers. In Sri Lanka, large segment of the population spends more than 50 percent of their income on food. Thus, this study investigates and assesses how international food price surge affects domestic inflation process in Sri Lanka. The empirical statistical results are derived by using a battery of parametric and non-parametric econometric techniques using monthly data of price series for the period from 2003M1 to 2013M12. The co-integration analysis results confirm that global food prices, domestic prices are co-integrated. Therefore, Sri Lankan government needs to develop a safety net program for the poor and a longer term poverty reduction strategy. Policy attention needs to shift towards efforts to increase food production. The results of this study have various policy implications for monetary policy, food and agricultural policy and trade policy for Sri Lanka.
\end{abstract}

Keywords: co-integration, error correction model, food price inflation, global price transmission

\section{Introduction}

Following globalization, the interdependency of each country has increased. Over the past few decades, many developing and emerging countries have become more integrated into the global economy. International trade, food commodities in particular, has become more important to the most of these countries. Global commodity prices have recently at least since 2003 exhibited high and increasing with highly volatile and persistent movements. The Food and Agriculture Organization (FAO)-Global Information Early Warning System (GIEWS) shows the up to date global food price information. There were unexpected price spikes in 2007/08 and 2010 for major global food commodities. It is now widely believed that food price shocks pass-through, at least partially, to final consumer prices so that global food prices and domestic prices co-integrated. Even though domestic policies affect prices, they cannot prevent the covariations of domestic prices with world prices in the long run (Mundlak \& Larson, 1992). United Nations Economic and Social Commission for Asia and the Pacific (United Nations ESCAP, 2011) has shown that Sri Lanka is also experiencing unexpected price pressures driven by higher global food prices.

Comparing 2013M12 with 2003M1, world market prices increased by 118.5 percent for food price, 114.8 percent for meat, 194.1 percent for dairy products, 97.6 percent for cereals, and 91 percent oil (FAO, 2013). Domestic price in Sri Lanka increased 153.5 percent for consumer price for all items, 179.8 percent for consumer price for food items (Department of Census and Statistics (DCS), 2013). These recent food commodity price increases have been attributed to a number of different factors such as rapid growth in emerging economies, rising global population, diversion of food production for use in energy products, rising cost of oil, weather shocks, US dollar depreciation, low interest rate in the US, speculative activities, low food stocks and policy measures (Johnson, 2008).

The households who spend more on food in their income, net food buyers, are more affected by increasing food prices. Advanced economies spend the least around 16 percent of their total household expenditure on food (Wu, 2004). The proportion of disposable income spent on food is around 10-15 percent for most Organization for Economic Co-operation (OECD) countries. By contrast, the average household in the developing world spends 
roughly half of its total budget on food. Countries in South Asia spend more than 50 percent of their total expenditure on food (Asian Development Bank (ADB), 2011). Poor households in developing countries allocate more than 60 percent of total household expenditure to food. As food expenditure carries large weight in the consumer price index (CPI) of many of the Asian economies including Sri Lanka (Table 1), food price inflation has caused general inflation hence lower their purchasing power.

Table 1. Food weights in consumer price index in Asia 2010

\begin{tabular}{cccccc}
\hline Economy & Share (\%) & Economy & Share (\%) & Economy & Share (\%) \\
\hline Bangladesh & 58.84 & Indonesia & 36.20 & Singapore & 22.05 \\
Cambodia & 44.78 & Korea, Republic & 14.04 & Sri Lanka & 45.50 \\
China & 30.20 & Malaysia & 31.40 & Taipei, china & 26.08 \\
Hong Kong & 26.67 & Pakistan & 40.34 & Thailand & 33.01 \\
India & 46.19 & Philippines & 46.58 & Vietnam & 39.93 \\
\hline
\end{tabular}

Source: ADB, 2011

Thus, food price surge during recent years has aroused intense concern worldwide about the impact on the poor in developing and emerging countries. Generally, emerging and developing economies are more vulnerable to an increase in world commodity prices than developed economies (International Monetary Fund (IMF), 2008).

In a globalized world, high world food prices are transmitted to domestic economy. The impact of high food prices has adverse impact on economy and social sector of many countries, in particular in food importing developing countries, where net buyers are large in number including all urban poor and majority of rural poor. The most (90 percent) of the global poor (income below 1.25\$/day) live in countries where domestic food prices respond to international prices (Kalkuhl, 2014). Rising food prices erode the purchasing power of net buyers of food and forcing them to reduce non-food spending and shift to cheaper foods. At the national level, food importing countries face balance-of-payment problem as the cost of food imports rose. In addition, the cost of operating food aid budgets and nutrition programs at the national and international level rise. In some of the countries, high food prices are a very sensitive political issue and led social unrest.

High food prices have increased world hunger (Ivanic \& Matin, 2008). The rising prices have increased number of undernourished populations (Mahendra Dev, 2013). Increasing food prices affect the number of people who are under poverty (ESCAP 2011, ADB, 2008a, 2008b, 2011). The impact of the global food price increases has been severe in Sub-Saharan Africa (SSA) which is a net importer of food (Minot, 2011).

Higher food prices may increase food insecurity and undermine population health (Lee, Lim, Lee \& Park, 2013). High food prices can have impact on children's health and education and having long term impact on children's health psycho-social well-being (Dercon \& Sanchez, 2008). Thus, it may retard human development, and lowering labour productivity of the economy in the long run.

General inflation could rise due to higher food prices. If wages could rise due to food prices, inflation could spiral, causing inflationary expectations with general price level rising further. Food prices have been a key driver of the sharp rises and falls in general inflation in recent years (Ferrucci, Rodriguez, \& Onorante, 2010). Hence, high and increasing food prices pose a significant policy challenges for developing and emerging countries where households spend a larger share of their income on food (Kelbore, 2013).

South Asia that includes Sri Lanka is the vulnerable region to food price inflation. According to International Food Policy Research Institute (IFRI), South Asia and SSA are the regions with highest Global Hunger Index (GHI) scores and the highest poverty rates (IFRI, 2008, 2013). Sri Lanka's rank based on 2013 GHI scores $(\mathrm{GHI}=15)$ comes under serious category.

Sri Lanka is a small open and dependent economy that is a price taker in world markets. Food sectors depend on imports. Sri Lanka is highly vulnerable to shocks in the international food prices since the food consumption basket has large food import component and large number of households spend large share of their income on food. The share of food and beverages imports expenditure of total consumer goods imports expenditure is around 50 percent for the period of 2009-2012 (Central Bank of Sri Lanka (CBSL), 2013). Food expenditure share in Colombo CPI which is computed only based on information from the Colombo municipal council in the Colombo district (out of 25 districts) in Sri Lanka is 41 percent in 2006. The food component counts around 67 percent in the Wholesale Price Index. However, food has largest weight more than 50 percent in the average household's consumption basket which is based on all districts in Sri Lanka (DCS, 2012). More than 80 percent of total population lives in rural and estate sectors in Sri Lanka (DCS, 2012). Large segment of the population in 
Sri Lanka, mostly from rural and estate sectors spends more than 50 percent (in the range of 50 to 70 percent) of their income on food. Many households depend on agricultural commodities for their income and food consumption. They are net buyers of staple foods. Thus average food inflation became a large source of inflation in Sri Lanka. Food and Non-alcoholic beverages contribution to the annual average overall inflation has higher percentages in Sri Lanka (Table 2).

Table 2. Contribution of Food and Non-alcoholic beverages to General Inflation increases

\begin{tabular}{lc}
\hline Year & Contribution to annual average increases (\%) \\
\hline 2010 & 5.8 \\
2011 & 59.9 \\
2012 & 29.3 \\
2013 & 52.0 \\
\hline
\end{tabular}

Source: Annual Reports 2013, Central Bank, Sri Lanka.

The main food items of imports (percent of total supply) in Sri Lanka are wheat (100 percent), sugar (90 percent), milk powder ( 85 percent), pulses and nuts ( 77 percent), meat, maize, big onion (50 percent), potato, Maldives' fish and rice, whereas wheat and maize are used as intermediate goods. Food and beverages, wheat and maize account approximately in the range of 9-12 percent of total import expenditure in Sri Lanka.

Figure 1 shows the evolution of food price in world and various consumer and producer prices in Sri Lanka. The features of these price dynamics are (i) food prices are more volatile, since 2007, there is sharp increases and high volatility in global food prices, (ii) upward movement and global food price and domestic food price are co-moved. (iii) first moment (mean) and second moment (volatility) of these price series distributions change over time. These prices may have random walk component and a stationary component, $p_{t}=w_{t}+z_{t},($ Stock \& Watson, 1988). Thus, these prices are made up of a stochastic trend and stationary deviations around trend.

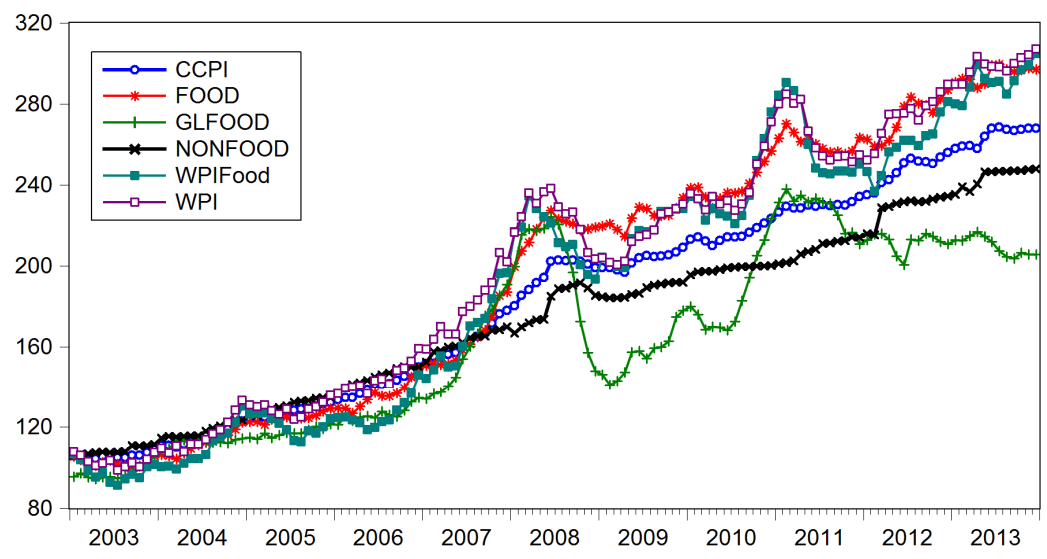

Figure 1. Evolution of domestic and world food price series

Source: Author's calculation using FAO Price Index data and all domestic price indices from Census and Statistics Department, Sri Lanka, 2013

Note: CCPI=Colombo Consumer Price Index, CCFPI=Colombo Consumer Food Price Index, GFPI= Global Food Price Index, WFPI=Wholesale Food Price Index, WPI=Wholesale Price Index

Given the structure of the Sri Lankan economy, food prices have a significant inter linkages between global food prices and domestic prices. The inter relationship between world food prices and domestic prices provides insights into marketing efficiency, as well as consumer and producer welfare.

To our knowledge, that there remain scarce in-depth in terms of econometric analysis with little systematic empirical evidence on the global food price transmission to domestic prices in Sri Lanka. ADB, FAO, World Bank publications show that there are large amount of literature on this issue for Africa, Latin America, Advanced economies, developing Asia consisting Pakistan, India, Vietnam, Philippine and Bangladesh. Carrasco and Mukhopadhyay (2012) have studied food price escalation in South Asia including Sri Lanka. However, this 
study has not focused on global food price transmission issue. There are no comprehensive studies about the global food price transmission for Sri Lanka. This study intends to fill this gap in the literature by providing a comprehensive study of global food price transmission to domestic prices in Sri Lanka.

This study attempts to answer the following questions: i) to what extent world food prices pass-through domestic prices in Sri Lanka? ii) is there long run relationship between global food price and domestic prices in Sri Lanka?. The extent of transmission is a fundamental and important issue because it is domestic prices that affect the welfare of poor consumers; hence it has important implications for economic welfare.

The objective of this study is to analyse in-depth the pass-through effects of international food prices to producer and consumer prices in the domestic inflation dynamics in Sri Lanka for the periods of 2003M1-2013M12. In particular, this investigation will show the extent and speed of transmission of international food price changes to the domestic prices in Sri Lanka. This study will uncover a robust empirical relationship between GFPI and domestic prices.

The structure of the paper is as follows. Section 2 briefly reviews the literature. Section 3 describes data and methodology of the study. Section 4 discusses the empirical results obtained from various econometric techniques applied in this study and the final section concludes, and gives some recommendations from the results obtained.

\section{Literature Review}

In this section, we briefly overview the existing works about global price transmission to domestic prices. In the literature, quantitative results are not directly comparable due to differences in data sources, sample periods, time frequencies, specification of the employed model, estimation methodologies, analyzed goods, countries under study. However, these studies provide a qualitative indication of broad trends and regularities which is useful for the new research.

The literature in the area of food price transmission shows a group of stylized facts (SF), (i) the food price pass through varies largely depending on the product category, (ii) the food price pass through differs across countries, (iii) the size of food price pass through has changed over time, (iv) the pass through to producer prices is higher than to consumer prices, (v) the food price pass through is asymmetric.

In recent years, there have been a large number of studies that have investigated the transmission of world food prices to domestic economy. For some examples: Myers (1992), Minot (2009), Shawarby and Selim (2012), Jalil and Tamayo (2011), Van Duyne (1982), Albers, Ronald and MargaPeeters (2011) and El- Sakka et al. (2005), Rapsomanikis (2011), Lee and Park (2013), Mudlak and Larson (1992), Ardeni (1989), Hazell, Jaramillo and Williamson (1990), Dawe (2008, 2009). Imai, Gaiha and Thapa (2008), Morriset (1998) and Conforti (2004).

Most of them found transmission was incomplete, and some are asymmetric. Further, global food price is significantly contributing to domestic inflation. Most of the study area was African countries. Some examples are Abdulai (2000) for Ghana, Rashid (2004) for Uganda, Lutz, Kuiper and Van Tilburg (2006) for Benin, Negassa and Meyers (2007) for Ethiopia, Van Campenhout (2007) for Tanzania, Rashhid (2011) for Ethiopia and Kelbore (2013) for Ethiopia. However, there were few studies about specific country studies about this issue in South Asia, in particular Sri Lanka.

\section{Data and Methodology}

In this section we present the approach in detecting global food price transmission to domestic prices in Sri Lanka. This study adopts a simple model based on the Law of One Price (LOP) to express the relationship between global food prices and domestic prices and test the transmission effect.

\subsection{Price Transmission Mechanism}

Price transmission is when a change in one price causes another price to change. This study concentrates on the spatial price (horizontal) transmission from global markets to domestic market prices of Sri Lanka. The transmission mechanism of global food prices is the way in which food price changes affect economic activity and inflation through several channels. This research on the transmission mechanism seeks to understand how these channels work in the context of dynamic, stochastic situation.

\subsection{Analytical Framework}

The analytical framework draws on the LOP (Ardeni, 1989). Price changes originating from the foreign sector can be divided into two transmissions mechanisms: one coming from import price in foreign currency terms and the other is price changes from exchange rate changes. Both a depreciation of the currency and an increase in import prices are expected to lead to an increase in the domestic price level. 
The LOP is in its strict form as $\mathrm{P}_{\mathrm{i}, \mathrm{t}}^{\mathrm{d}}=\mathrm{ER}_{\mathrm{t}} * \mathrm{P}_{\mathrm{i}, \mathrm{t}}^{\mathrm{w}}$ where ER is nominal exchange rate (units of domestic currency per unit of foreign currency: RS/USD), $\mathrm{P}^{\mathrm{w}}$ is world (foreign) price, $\mathrm{P}^{\mathrm{d}}$ is domestic price for specific (i) commodity, $t$ time period. In statistical terms, $\left(\mathrm{P}_{\mathrm{i}, \mathrm{t}}^{\mathrm{d}}=\mathrm{ER}_{\mathrm{t}} * \mathrm{P}_{\mathrm{i}, \mathrm{t}}^{\mathrm{W}} \mathrm{e}^{\varepsilon_{\mathrm{t}}}\right)$, the relationship between the variables can be written in natural log form (depicted in lower case) as

$$
\mathrm{p}_{\mathrm{t}}^{\mathrm{d}}=\beta_{0}+\beta_{1} \mathrm{p}^{\mathrm{w}}+\beta_{2} \mathrm{er}_{\mathrm{t}}+\varepsilon_{\mathrm{t}}, \quad \varepsilon_{\mathrm{t}} \sim \operatorname{IID}\left(\mu, \sigma^{2}\right)
$$

We implicitly assume that ER, is a exogenous variable as Sri Lanka is a price taker. $\beta_{1}$ is the price transmission elasticity. Commodity market arbitrage and purchasing power parity suggest that in the short run, prices of similar products in varied markets might differ. However, arbiters will prevent the various prices from moving too far apart even if the prices are nonstationary. Hence, our empirical model is Equation (1). From this model, we form five models for each domestic price series separately to study the transmission effect of global food prices. As shown in Equation (2)-(6)

$$
\begin{aligned}
L C C P I & =f(L G F P I, L U S D, D) \\
L C C F P I & =f(L G F P I, L U S D, D) \\
L C C N F P I & =f(L G F P I, L U S D, D) \\
L W F P I & =f(L G F P I, L U S D, D) \\
L W P I & =f(L G F P I, L U S D, D)
\end{aligned}
$$

The degree of pass-through from international food price changes to domestic price changes is estimated using the above models. First, we characterize the data using exploratory data analysis, contemporaneous correlations, and unit root tests. Then transmission effects are examined using parametric approach; co-integration technique. Graphical displays are used to explore the underlying dynamic behavior of the domestic price series and global food price series and their hidden underlying relationships.

Then, three standard unit-root test techniques, namely, Augmented Dickey Fuller (ADF) test proposed by Dickey and Fuller, (1979, 1981), PP test proposed by Phillips and Perron (1988) and KPSS test proposed by Kwiatkowski, Phillips, Schmidt and Shin (1992) conducted to identify the order of the integration of each price series. Three tests are done in order to get robust results.

After determining the order of the integration of the series, we test for the existence of any long run relationship between domestic prices and global food prices. Theory of co-integration gives a way to reconcile findings of non-stationarity with the possibility of testing relationship among the levels of economic variables (Granger, 1986). In this study, we employed system based reduced rank regression approach proposed by Johansen (1991, 1995) test which has the advantage that both estimation and hypothesis testing are performed in a unified framework (Engle \& Granger, 1987).

\subsubsection{Cointegration Test - The Johansen's Procedure}

Cointegration and error correction models (ECM) provide an analytical tool that can focus price transmission, in testing notions such as completeness, speed, and asymmetry of the relationship between prices (Rapsomanikis, Hallam \& Conforti, 2006). Johansen method has several superior properties (Gonzalo, 1994). Thus, we employed Johansen $(1988,1991)$ and Johansen \& Juselius (1990) methods. Johansen's procedure starts with Vector Autoregression (VAR) model then re-parameterized in Vector Error Correction (VECM) form which exhibits co-integrating relations explicitly. If the variables are non-stationary and co-integrated, the adequate method to examine the relations is the VECM (Granger, 1988).

The standard linear vector error correction representation of the VAR model for the K variables has the form as

$$
\Delta \mathrm{Y}_{\mathrm{t}}=\Pi \mathrm{Y}_{\mathrm{t}-1}+\sum_{\mathrm{i}=1}^{\mathrm{p}-1} \Gamma_{\mathrm{i}} \Delta \mathrm{Y}_{\mathrm{t}-\mathrm{i}}+\Psi \mathrm{X}_{\mathrm{i}}+\varepsilon_{\mathrm{t}}
$$

where $\Delta$ is the first difference operator, $\mathrm{Y}$ is a $(\mathrm{kx} 1)$ vector of $\mathrm{K}$ potential endogenous variables $\Pi$ is long run response coefficient matrix, $\Gamma_{\mathrm{i}}$ is short run coefficient matrix, $\mathrm{p}$ is the order of $\operatorname{VAR}, \varepsilon_{\mathrm{t}} \sim \operatorname{IID}(0, \Sigma)$. The rank of $\Pi$ is denoted by $r$ and decided based on the statistical significance of its eigenvalues. The rank of a matrix is equal to the number of its characteristics roots (eigenvalues $\left(\lambda_{i}\right)$ ). If the rank, r, is $0<\mathrm{r}<\mathrm{k}$ then $\Pi$ can be partitioned as $\Pi=\alpha \beta^{\prime}$. Now the error correction model becomes as

$$
\Delta \mathrm{Y}_{\mathrm{t}}=\alpha \beta^{\prime} \mathrm{Y}_{\mathrm{t}-1}+\sum_{\mathrm{i}=1}^{\mathrm{p}-1} \Gamma_{\mathrm{i}} \Delta \mathrm{Y}_{\mathrm{t}-\mathrm{i}}+\Psi \mathrm{X}_{\mathrm{i}}+\varepsilon_{\mathrm{t}}
$$


where $\beta$ coefficients provide the long run response. The elements of $\alpha$ matrix measure the speed of adjustments to the long run equilibrium. The sign and magnitude of the coefficient of the error correction term (ECT) helps in figuring out the short term adjustment process. If the value of the coefficient falls between -1 and 0 , the ECT tends to cause the dependent variable to converge monotonically to its long run equilibrium time path. A positive value of the coefficients of the ECT or a value smaller than $(-2)$ will cause dependent variable to diverge. If the value is between -1 and -2 , then the ECT will produce dampened fluctuations in the dependent variable about its equilibrium route (Alam \& Quazi, 2003). A larger value $\alpha_{i}$ indicates a faster convergence toward long run equilibrium in cases of short run deviations from long run equilibrium. The estimates of $\alpha_{i}$ are important to the policy makers and investors.

The appropriate lag length for the co-integration test was selected based on Akaike's Information Criterion (AIC), the Schwarz Information Criterion (SIC) and Hannan-Quinn Information Criterion (HIC). The cointegration test Johansen approach is based on two different likelihood ratio (LR) statistics which are:

The trace test statistic,

$$
\lambda_{\text {trace }}(r)=-\mathrm{T} \sum_{\mathrm{i}=\mathrm{r}+1}^{\mathrm{n}} \ln \left(1-\hat{\lambda}_{\mathrm{i}}\right)
$$

The maximal eigenvalue Statistics,

$$
\lambda_{\text {max }}(\mathrm{r}, \mathrm{r}+1)=-\mathrm{T} \ln \left(1-\hat{\lambda}_{\mathrm{r}+1}\right)
$$

where $r$ is the number of co-integration vectors. These statistics are used to assess the number of co-integrating relationships among the variables in this analysis. Critical values for both statistics are provided by Johansen \& Juselius (1990). A very useful feature of the Johansen procedure for co-integration is that it allows us to test for restricted forms of the co-integrating vectors. Restrictions are imposed by substituting them into the relevant $\alpha$ or $\beta$ matrices as appropriate. First step in the Johansen cointegration analysis is to determine the optimal lag. In this study, the optimal number of lags was determined based on model selection criteria such as AIC, HQIC and SIC. The smallest value of these criteria is used to select optimal lag length. Then ECM is estimated.

\subsubsection{Impulse Response Function}

We use impulse response function (IRF) analysis in this study to provide dynamic simulations of the effects of shocks of known size and duration in global food price on domestic prices. An IRF traces the response of current and future values of the endogenous variables to a one standard deviation shock through the dynamic structure of the VAR. Plots of the IRF over time provide a graphical illustration of the period by period simulation, describing both adjustment path and long run effect on the domestic prices in response to the shock in global food price. Assuming that all series in $Y_{t}$ are stationary and they can be expressed in a vector moving average (VMA) representation as given below.

$$
\begin{aligned}
& Y_{t}=\mu+\theta(L)^{-1} \varepsilon_{t} \\
& Y_{t+s}=\sum_{i=0}^{\infty} \Psi \varepsilon_{t+n-i},
\end{aligned}
$$

The IRF is defines as

$$
\left\{\Psi_{\mathrm{n}}\right\}_{\mathrm{i}, \mathrm{j}}=\frac{\partial \mathrm{Y}_{\mathrm{i}, \mathrm{t}+\mathrm{n}}}{\partial \varepsilon_{\mathrm{j}, \mathrm{t}}}
$$

The matrix $\Psi$ can be interpreted as that its $(i, j)$ element measures the consequences of a one unit increase in the $j^{\text {th }}$ variable's innovation at date $\mathrm{t},\left(\varepsilon_{j t}\right)$ for the value of the $i^{\text {th }}$ variable at time $t+n$ holding all other innovations at all dates constant. The IRF is derived by plotting these elements as a function of $s$. The advantage of examining impulse response functions is that they show the size of the impact of the shock plus the rate at which the shock dissipates, allowing for interdependencies.

\subsection{Data}

This study uses monthly data on domestic consumer prices, producer prices and global food prices. The data cover the period of January 2003 to December 2013 which gives a total of 132 observations. The period of 2003 was used as a starting time because international oil, cereal and fertilizer prices and domestic food price started to rise exponentially. Price indices are used as a proxy for the price series. The variables used in this study are defined as in the Table 3. 
Table 3. Definition of Variables used in the study

\begin{tabular}{|c|c|c|}
\hline Price Index & Log transformation & Inflation \\
\hline $\begin{array}{llll}\begin{array}{l}\text { Colombo } \\
\text { (CCPI) }\end{array} & & & \\
\end{array}$ & $\mathrm{LCCPI}_{\mathrm{t}}=\ln \left(\mathrm{CCPI}_{\mathrm{t}}\right)$ & $\pi_{t, c p i}=\left(L C C P I_{t}-L C C P I_{t-1}\right) * 100$ \\
\hline CCPI Food $\left(\right.$ CCFPI $\left._{t}\right)$ & LCCFPIt $=\ln$ (CCFPIt) & $\pi_{t, c f p i}=\left(L C C F P I_{t}-L C C F P_{t-1}\right) * 100$ \\
\hline CCPI Non-food (CCNFPIt) & LCCNFPIt $=\ln ($ CCNFPIt $)$ & $\pi_{t, c n f p i}=\left(L C C N F P I_{t}-L C C N F P_{t-1}\right) * 100$ \\
\hline Wholesale Price Index (WPIt) & LWPIt $=\ln (\mathrm{WPI})$ & $\pi_{t, w p i}=\left(L W P I_{, t}-L W P I_{, t-1}\right) * 100$ \\
\hline Wholesale Food Price Index (WFPI & LWFPIt= $\ln ($ WFPIt $)$ & $\pi_{t, w f p i}=\left(L W F P I_{t}-L W F P I_{t-1}\right) * 100$ \\
\hline Global Food Price Index $\left(\right.$ GFPI $\left._{t}\right)$ & $\mathrm{LGFPI}_{\mathrm{t}}=\ln \left(\mathrm{GFPI}_{\mathrm{t}}\right)$ & $\pi_{t, G f p i}=\left(L G F P I_{f, t}-L G F P I_{f, t-1}\right) * 100$ \\
\hline
\end{tabular}

*Note: Food category consists of bread and cereals, meat, fish and sea food, milk, cheese and eggs, oil and fats, fruits, vegetables, sugar, jam, honey, chocolate and confectionary food products. Non-alcoholic beverages, consist of coffee, tea, cocoa, mineral water, soft drinks fruit and vegetable juice.

The variable GFPI is collected from FAO web site and domestic consumer prices CCPI, CPFPI and CCNFPI are collected from DCS, Sri Lanka. WPI, WFPI, Exchange rates (ER) data are collected from the Central Bank, Sri Lanka. The key currency is the US dollar in all external trade in Sri Lanka. Therefore, we use RS/USD exchange rate in this study. Exchange rate variable is assumed to be exogenous.

\section{Empirical Results}

This section focuses on the analysis of the empirical results from the performed econometric and statistical tests. Our investigation highlights a number of interesting results. Contrary to the existing literature, we find evidence of a statistically and economically significant food price pass-through in Sri Lanka.

\subsection{Preliminary Data Analysis-Diagnostic Check}

The time series plot in Figure 1shows the evolution of global food price and domestic prices. They move upward closely. Local food price has been higher and increasing trend compared to global food price dynamics. Global food price series are more volatile than domestic price series. However, local food prices in Sri Lanka mirrored global food price movements. Figure 2(b) shows the behavior of various commodity prices in the world market. Figure 2(a) shows the comparison of domestic prices with global food and oil price behavior during the study period. They indicate that domestic prices are co-moved with global food prices. Simple statistical contemporaneous correlation analysis confirms the strong positive correlation between global food price and local food prices $(0.94)$, overall consumer price $(0.91)$, wholesale food price $(0.95)$ wholesale price $(0.96)$.

Global food price inflation has asymmetric effects on domestic price behaviour. Pass-through effects of food price hikes are significantly higher than that of food price falls in Sri Lanka. However, while domestic prices rise in tandem with global food prices they do not tend to decline to the same extent that global food prices do. This may be owing to local market inefficiencies, domestic monopolies, and limited global trade integration.

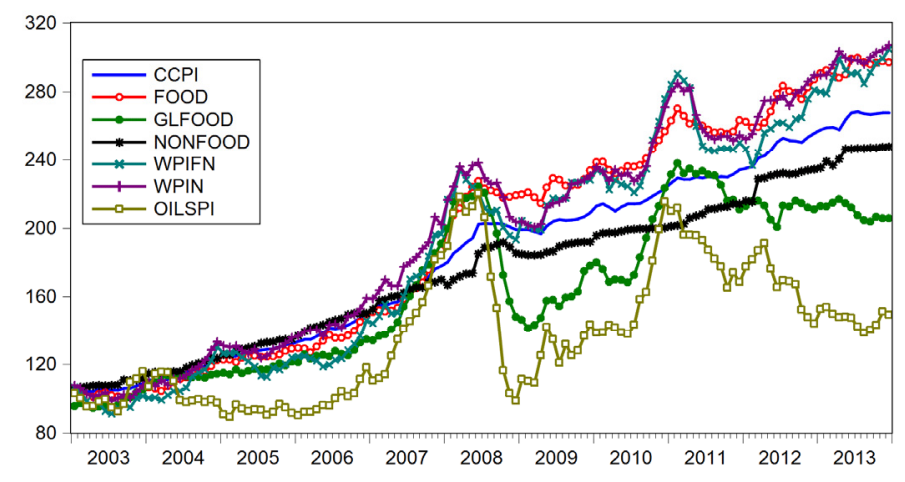




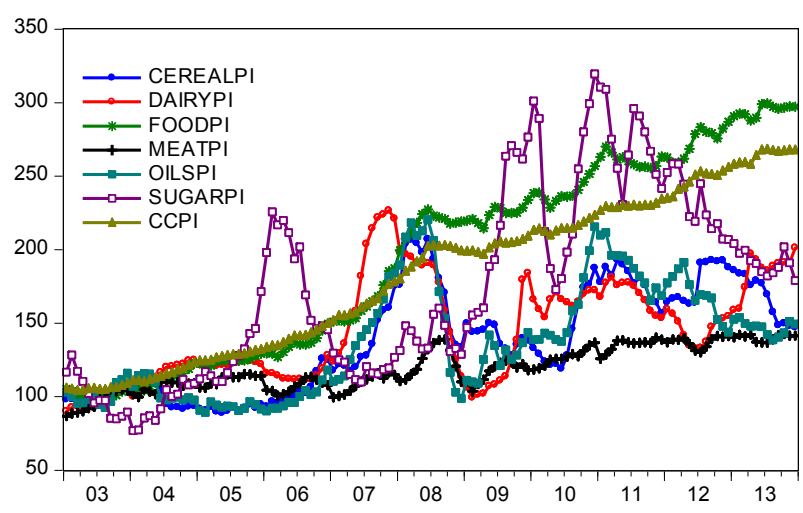

(b)

Figure 2. Food price dynamics in Sri Lanka and World

Source: Data from Department of Census and Statistics, Sri Lanka, FAO website and author ${ }^{1}$ s calculation

Further, we can observe the underlying dynamic inter relationship between global food price and domestic prices from the confidence ellipse graphs in Figure 3. The overall shape of the confidence ellipse indicates that WFPI, CCPFI, CCPI and WPI are highly and positively correlated. The kernel fit indicates that the dynamic relationships are nonlinear and positive.

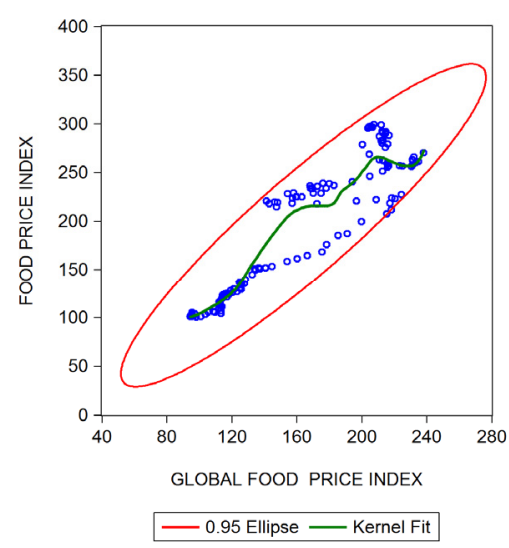

(a)

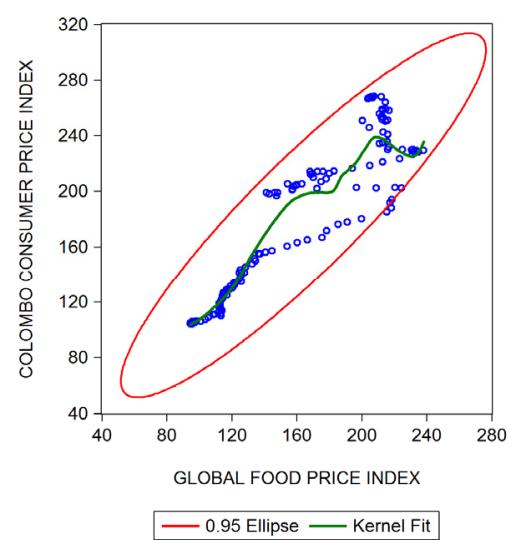

(c)

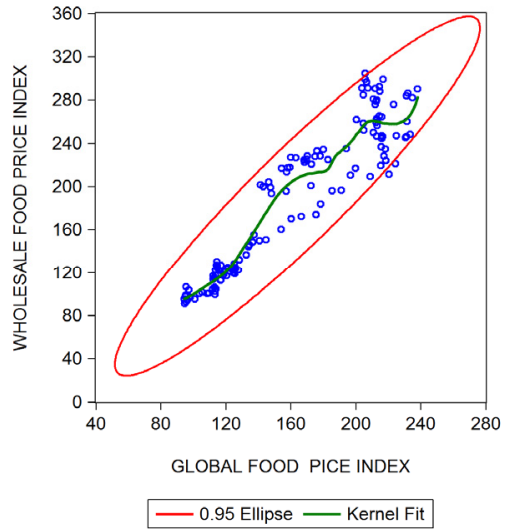

(b)

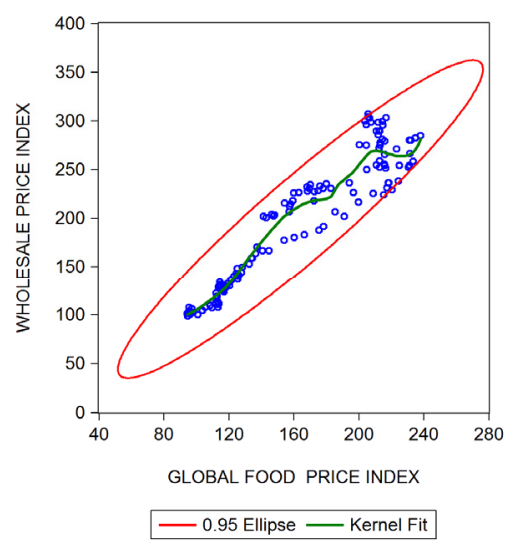

(d)

Figure 3. Inter-relation between Global food price index vs Colombo Consumer Price Iindex, Colombo Consumer Food Price Insex, Wholesale Price Index, Wholesale Food Price Index 
Based on the visual inspection of the line graph of each variable, suitable ADF, PP, KPSS unit root tests (none or intercept or intercept with trend) are selected. The order of integration of the food price series is assessed by the ADF test, PP test and the KPSS test. Three unit root tests are done in order to check any contradiction results exist. As all three test results are similar, ADF test results are only reported in the text in Table 4 . The results of PP test and KPSS test are not shown to economize on space. Unit root test results show that all these price series in level are non-stationary and I(1). These series in first difference are stationary, I(0). All "P" values of the ADF test statistic for each variable in this study are less than 0.05 . The first difference series are strongly mean reverting and $\mathrm{I}(0)$. Therefore, all the series in this study are $\mathrm{I}(1)$ in level form.

Table 4. ADF Unit root test results for level data

\begin{tabular}{ccccc}
\hline \multirow{2}{*}{ Series } & \multicolumn{2}{c}{ Level with intercept and trend } & \multicolumn{2}{c}{ First Difference with intercept and trend } \\
\cline { 2 - 5 } & ADF statistic & P value & ADF statistic & P value \\
\hline LCCPI & -0.8059 & 0.9617 & -7.8894 & 0.0000 \\
LCCFPI & -1.4666 & 0.8361 & -7.2237 & 0.0000 \\
LCCNFPI & -1.2503 & 0.8952 & -11.045 & 0.0000 \\
LGFPI & -3.1000 & 0.1107 & -6.0333 & 0.0000 \\
LWFPI & -2.2557 & 0.4546 & -8.7396 & 0.0000 \\
LWPI & -1.5059 & 0.8229 & -10.0361 & 0.0000 \\
LUSD & -2.7435 & 0.2213 & -7.6999 & 0.0000 \\
Critical value (5\%) & -3.4447 & & & -3.4447 \\
\hline
\end{tabular}

${ }^{*}$ Mackinnon (1996) one-side p-value

\subsection{Cointegration Tests}

This section describes the econometric analysis of the relationship between global food prices and domestic prices in Sri Lanka. Co-integration technique and ECM are used to describe the transmission. Preliminary data analysis showed that all price time series used in this study are non-stationary, I(1). We employed Johansen test to find out the long run relationship between the domestic and world food prices using full information Maximum Likelihood method. First, we estimated appropriate lag length for the co-integration test using lag selection criteria; AIC, SC and HC. For all five models, we selected optimal lag based on the basis of AC, SC, HC. The results show that optimal lag was 2 for all models. However, for WFPI and WPI model, we use one lag in order to satisfy long run equilibrium. Then, we employed co-integration test for all five domestic price models.

The results of the Johansen co-integration test for model 1 are presented in Table 5. Domestic prices are deliberately chosen as the dependent variable (normalized to one) to see the global food price transmission to the domestic prices in Sri Lanka. Using Trace statistic and Maximum Eigenvalue statistic, the sequential procedure is done to find the number of co-integrating relations. Table 5 provides the evidence from both trace and Maximum eigenvalue tests for rank determination for model 1.

Table 5. Johansen and Juselius Co-integration Rank Test for the Model 1

\begin{tabular}{cccccccccc}
\hline Ho & $\mathrm{H}_{1}$ & $\begin{array}{c}\text { Trace } \\
\text { Statistic } \\
\lambda_{\text {Trace }}\end{array}$ & $\begin{array}{c}\text { Critical } \\
\text { value } \\
(5 \%)\end{array}$ & Prob** & $\mathrm{H}_{\mathrm{o}}$ & $\mathrm{H}_{1}$ & $\begin{array}{c}\text { Max-Eigen } \\
\text { Statistic } \lambda_{\text {Max }}\end{array}$ & $\begin{array}{c}\text { Critical } \\
\text { Value } \\
(5 \%)\end{array}$ & Prob** $^{* *}$ \\
\hline $\begin{array}{c}\text { None } \\
(\mathrm{r}=0)^{*}\end{array}$ & $\mathrm{r} \geq 1$ & 45.816 & 35.192 & $0.002^{*}$ & $\begin{array}{c}\text { None } \\
(\mathrm{r}=0)^{*}\end{array}$ & $\mathrm{r}=1$ & 28.696 & 22.299 & $0.005^{*}$ \\
$\begin{array}{c}\text { At most } \\
1\end{array}$ & $\mathrm{r} \geq 2$ & 17.119 & 20.261 & 0.128 & $\begin{array}{c}\text { At most } \\
1(\mathrm{r}=1)\end{array}$ & $\mathrm{r}=2$ & 12.759 & 15.892 & 0.146 \\
$\begin{array}{c}\mathrm{r} \leq 1) \\
\text { At most } \\
2\end{array}$ & $\mathrm{r} \geq 3$ & 4.359 & 9.164 & 0.361 & $\begin{array}{c}\text { At most } \\
2(\mathrm{r}=2)\end{array}$ & $\mathrm{r}=3$ & 4.359 & 9.164 & 0.361 \\
$(\mathrm{r} \leq 2)$ & & & & & & & & & \\
\hline
\end{tabular}

* 5 percent level significant Prob**= Mackinnon - Haug-Michelis(1999) $\mathrm{p}$ values

For model 1, the Johansen's test statistics; the Trace statistic and Maximum Eigenvalue statistic given in Table 5 indicate that $H_{0}: r=0$ the null hypothesis is rejected at 5 percent level. These results suggest that there is at 
least one co-integration relation among these variables. In the case of other models, we select the number of co-integration vectors using the same procedure. As there exist co-integration among these variables, there exists an error correction mechanism, so we employed VECM and report the results of VECM for each price model in Table 6. The co-integrating vector and speed of adjustment parameters are estimated for characterizing the extent of global food price transmissions and the disequilibrium behavior of prices respectively. The results reveal potential global food price transmission to domestic prices. These results are consistent with the simple correlation analysis discussed above. The first part of Table 6, i.e. 6A reports the long run parameter estimates while second part of the Table 6B reports the results for short run impact multiplier estimates and impact of exogenous variables. According to the results in Table 6A, GFP is co-integrated with all food and non-food domestic prices indicating that a long run relationship exists between GFP and all domestic food price series. As all variables are in natural $\log$ form, they indicate price transmission elasticity. They imply that when GFP increase by one percent domestic food price increase by 1.32 percent, overall consumer price increase by 1.10 percent, nonfood price increase by 0.66 percent, wholesale price increase by 1.13 percent and wholesale food price increase by 1.13 percent. Transmission elasticity is higher in magnitude for food prices compared to nonfood price. One interesting point is that global food price transmissions significantly increases the food prices in domestic economy and hence contribute to overall price inflation.

Table 6. Results of VECM -Sri Lanka

\begin{tabular}{|c|c|c|c|c|c|}
\hline \multicolumn{6}{|c|}{ A: Long Run Transmission Elasticity } \\
\hline & LCCPI & LCCFPI & LCCNFPI & LWFPI & LWPI \\
\hline \multirow[t]{2}{*}{ LGFPI } & $1.100^{* *}$ & $1.324 * *$ & $0.659 * *$ & $1.128^{* *}$ & $01.125^{* *}$ \\
\hline & [13.822] & {$[12.077]$} & {$[3.599]$} & [24.432] & [43.417] \\
\hline $\mathrm{C}$ & 0.404 & 1.366 & 2.188 & - & \\
\hline \multicolumn{6}{|c|}{ B: Short Run Pass-through Effects of Global Food Prices } \\
\hline & DLCCPI & DLCCFPI & DLCCNFPI & DLWFPI & DLWPI \\
\hline \multirow[t]{2}{*}{$\mathrm{D}(\mathrm{DV}(-1))$} & 0.173 & 0.431 & -0.055 & 0.148 & -0.048 \\
\hline & {$[1.958]$} & {$[5.00012]$} & {$[-0.645]$} & {$[1.644]$} & {$[-0.507]$} \\
\hline \multirow[t]{2}{*}{$\mathrm{D}(\mathrm{DV}(-2))$} & -0.124 & -0.239 & -0.005 & - & - \\
\hline & {$[-1.453]$} & {$[-2.818]$} & {$[-0.066]$} & & \\
\hline \multirow[t]{2}{*}{$\mathrm{D}(\mathrm{LGFPI}(-1))$} & 0.068 & 0.099 & 0.023 & 0.265 & 0.307 \\
\hline & {$[2.424]^{*}$} & {$[1.941]^{*}$} & {$[0.649]$} & {$[2.727]^{*}$} & {$[3.706]^{*}$} \\
\hline \multirow[t]{2}{*}{$\mathrm{D}($ LGFPI $(-2))$} & 0.052 & 0.049 & 0.066 & - & - \\
\hline & {$[1.735]$} & {$[0.927]$} & {$[1.757]$} & & \\
\hline \multirow[t]{2}{*}{ DUSD } & 0.123 & 0.195 & 0.175 & 0.379 & 0.214 \\
\hline & {$[2.097]^{*}$} & {$[1.822]^{*}$} & {$[2.264]^{*}$} & {$[1.705]^{*}$} & {$[1.190]$} \\
\hline \multicolumn{6}{|c|}{ C: Adjustment Speed } \\
\hline & LCCPI & LCCFPI & LCCNFPI & LWFPI & LWPI \\
\hline ECT & $\begin{array}{l}-0.016^{*} \\
{[-2.447]}\end{array}$ & $\begin{array}{l}-0.029 * \\
{[-3.586]}\end{array}$ & $\begin{array}{l}-0.015^{*} \\
{[-5.155]}\end{array}$ & $\begin{array}{l}-0.011^{*} \\
{[-1.774]}\end{array}$ & $\begin{array}{c}-0.016 \\
{[-2.778]}\end{array}$ \\
\hline
\end{tabular}

Note: DV refers dependent variable, ECT refers error correction term, ${ }^{* *}$ significant at 1 percent level

* Significant at 5 percent level, " $t$ " statistic values in [ ]

In short run, GFP is significantly increases CCPI, CCFPI, WFPI and WPI. Exchange rate depreciation has positive and significant impact on almost all price variables except WPI. The findings of VECM confirm the heterogeneity of price transmission in Sri Lanka. We have found that that price transmission is high for food prices compared to nonfood prices in the short run and log run.

This study finds that the coefficients of the ECT in all the models carry negative sign and statistically significant at 5 percent level. The negative sign indicates that each response variable moves downward towards long run equilibrium time path and that the stability of the corresponding model. The estimates of adjustment coefficients for each domestic prices of CCPI, CFPI, CNFPI, WPFI, and WPI are $-0.016,-0.029,-0.015,0.011$, and -0.016 , respectively. It implies that every month, the disequilibrium error is corrected in the speed of less than 5 percent. They show that the percentage of the deviation of the actual response variable from its long run equilibrium level (disequilibrium) is corrected each month. These results are consistent with the findings of Quiroz \& Soto (1995) and Conforti (2004). 


\subsection{Impulse Response Function}

A positive one standard deviation shock to the global food prices is simulated and the IRFs are presented in Figure 4. The impulse responses of LCCPI indicate the direct inflationary effects due to LGFP increases. CCPI increases faster till up to five months then started to flatter or decline very slowly. A positive shock to global food price (GFPI) has an immediate positive impact on domestic food prices (CCFPI) and CCFPI increase up to five months then declines. Nonfood price is also increase till nine months. This longer period may be due to secondary effects. Every response of domestic prices is all positive at each responsive period. Overall, global food price induce price inflation in Sri Lanka.

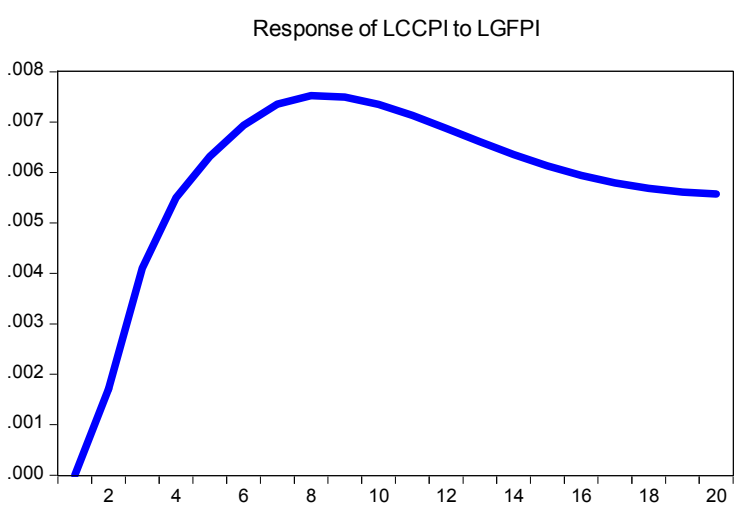

(a)

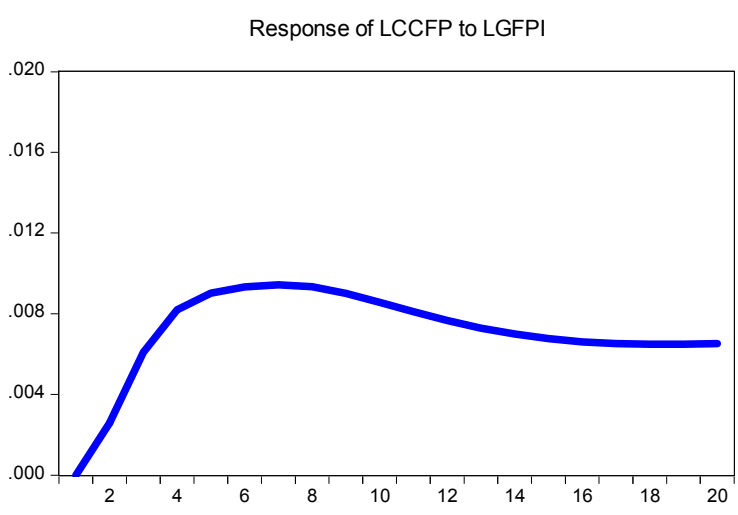

(b)

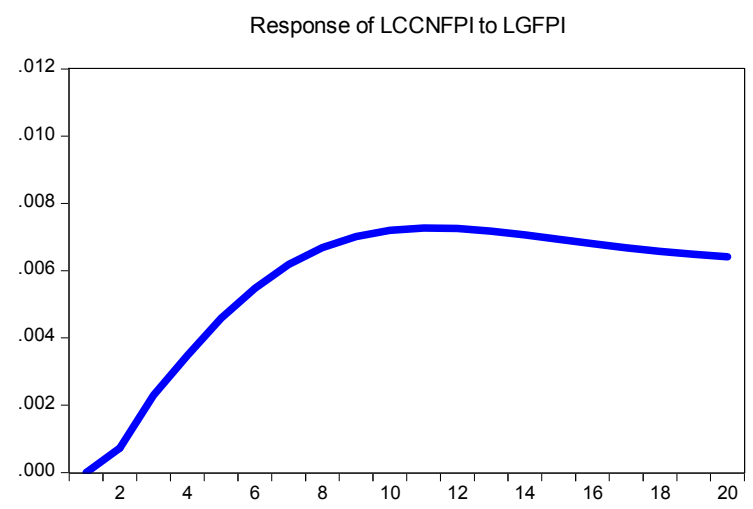

(c)

Figure 4. Impulse response of log of Colombo consumer price, log of Colombo consumer food price, log of Colombo consumer non food price to global food price

\section{Conclusions and Policy Implications}

We find evidence of statistically and economically significant international food price pass-through effects to domestic price inflation dynamics in Sri Lanka. The results of this study show that domestic prices have been co-moved with international food prices. The co-integration test results confirm that global food price cointegrated almost all domestic prices. Global food price does not influence statistically significantly nonfood price inflation in the short run. The increases in global food prices generate increases in headline inflation and domestic food inflation. Therefore, Sri Lankan government needs to develop a safety net program for the poor and a longer term poverty reduction strategy. Policy attention needs to shift toward efforts to increase food production, investing agricultural research, facilitating grain trade, promoting diversification in staples consumption. A few implications of our findings for the monitoring, modeling, and forecasting of food prices in Sri Lanka are worth mentioning. These results may provide valuable information for the food price policy and trade policy planning. Future empirical work in this area should strive for a more comprehensive analysis to investigate the aspects of international food price volatility transmission, nonlinearities and asymmetric price transmission. Thus, more has to be done in terms of short and long term policies to ensure food security and price stabilization. 


\section{Acknowledgements}

First author wishes to express his gratitude to Prof Jan G. De Gooijer, Prof H.P. Boswijk, Prof Dr. J.F. Kiviet, University of Amsterdam, The Netherlands.

\section{References}

Abdulai, A. (2000). Spatial price transmission and asymmetry in the Ghanaian Maize Market. Journal of Development Economics, 63(2), 327-349. http://dx.doi.org/10.1016/S0304-3878(00)00115-2

Alam, I., \& Quazi, R. (2003). Determinants of capital flight: an econometric case study of Bangladesh. International Review of Applied Economics, 17(1), 85-103. http://dx.doi.org/10.1080/713673164

Albers, Ronald, \& MargaPeeters. (2011). Food and energy prices, government subsidies and fiscal balances in South Mediterranean Countries. European Commission Economic Papers 437. Brussels: European Union.

Ardeni, P. G. (1989). Does the law of one price really hold for commodity prices?. American Journal of Agricultural Economics, 71(3), 661-669. http://dx.doi.org/10.2307/1242021

Asian Development Bank. (2008a). Food prices and inflation in developing Asia: Is Poverty Reduction Coming to End? Special Report, Manila.

Asian Development Bank. (2008b). Asian Development Outlook 2008 update: Responding to commodity shocks. Manila.

Asian Development Bank. (2011). Global food price inflation and developing Asia. Manila, Philippines.

Carrasco, B., \& Mukhopadhyay, H. (2012). Food price escalation in South Asia - a Serious and Growing Concern. ADB South Asia WP No:10 Manila, Philippines.

Central Bank of Sri Lanka. (2013). Annual Reports.

Conforti, P. (2004). Price Transmission in Selected Agricultural Markets. FAO Commodity and Trade Policy Research Working Paper No. 7. Food and Agriculture Organization (FAO), Rome.

Dawe, D. (2008). Have recent increases in international cereal prices been transmitted to domestic economies. The experience in seven large Asian countries. FAO-ESA Working Paper, 8(3), 1-12.

Dawe, D. (2009). Cereal Price Transmission in Several Large Asian Countries during the Global Food Crisis. Asian Journal of Agriculture and Development, 6(1), 1-12.

Department of Census and Statistics. (2012). Household Income and Expenditure Survey. Sri Lanka.

Dercon, S., \& Sanchez, A. (2008). Children and the Food Price Crisis. Department of International Development Queen Elizabeth House, University of Oxford.

Dickey, D. A., \& Fuller, W. A. (1979). Distribution of the estimators for autoregressive time series with a unit root. Journal of the American statistical association, 74(366a), 427-431. http://dx.doi.org/10.2307/2286348

Dickey, D. A., \& Fuller, W. A. (1981). Likelihood ratio statistics for autoregressive time series with a unit root. Econometrica: Journal of the Econometric Society, 1057-1072. http://dx.doi.org/10.2307/1912517

Engle, R. F., \& Granger, C. W. (1987). Co-integration and error correction: representation, estimation, and testing. Econometrica: journal of the Econometric Society, 251-276. http://dx.doi.org/10.2307/1913236

Ferrucci, G., Jiménez-Rodríguez, R., \& Onorante, L. (2010). Food Price Pass-Through in the Euro Area-The Role of Asymmetries and Non-Linearities. European Central Bank, Working Paper, 1168.

Food and Agriculture Organization (FAO). (2013). Website.

Food Policy Research Institute (IFRI). (2013). 2013 Global Hunger Index, The Challenge of Hunger, IFRI Issue brief 79.

Gonzalo, J. (1994). Five alternative methods of estimating long-run equilibrium relationships. Journal of econometrics, 60(1), 203-233. http://dx.doi.org/10.1016/0304-4076(94)90044-2

Granger, C. W. (1986). Developments in the study of cointegrated economic variables. Oxford Bulletin of economics and statistics, 48(3), 213-228. http://dx.doi.org/10.1111/j.1468-0084.1986.mp48003002.x

Granger, C. W. (1988). Some recent development in a concept of causality. Journal of econometrics, 39(1), 199-211. http://dx.doi.org/10.1016/0304-4076(88)90045-0

Hazell, P. B. R., Jaramillo, M., \& Williamson, A. (1990). The relationship between world price instability and the prices farmers receive in developing countries. Journal of Agricultural Economics, 41(2), 227-241. 
http://dx.doi.org/10.1111/j.1477-9552.1990.tb00638.x

Imai, K., Gaiha, R., \& Thapa, G. (2008). Transmission of world commodity prices to domestic commodity prices in India and China. School of Social Sciences (Economics), University of Manchester, UK. $\mathrm{http}: / / \mathrm{dx}$.doi.org/10.2139/ssrn.1265633

International Monetary Fund. (2008). Food and Fuel Prices-Recent Developments, Macroeconomic Impact and Policy Responses.

Ivanic, M., \& Martin, W. (2008). Implications of higher global food prices for poverty in low - income countries1. Agricultural economics, 39(s1), 405-416. http://dx.doi.org/10.1111/j.1574-0862.2008.00347.x

Jalil, M., \& Tamayo, E. (2011). Pass-through of International Food Prices to Domestic Inflation During and After the Great Recession: Evidence from a Set of Latin American Economies. Revista Desarrolloy Sociedad, Universidad de los Andes, CEDE, Bogotá, Colombia.

Johansen, S. (1988), Statistical analysis of cointegration vectors. Journal of economic dynamics and control 12(2), 231-254. http://dx.doi.org/10.1016/0165-1889(88)90041-3

Johansen, S. (1991). Estimation and hypothesis testing of cointegration vectors in Gaussian vector autoregressive models. Econometrica: Journal of the Econometric Society, 1551-1580. http://dx.doi.org/10.2307/2938278

Johansen, S. (1995). Likelihood-based inference in cointegrated vector autoregressive models. Oxford University press. http://dx.doi.org/10.1093/0198774508.001.0001

Johansen, S., \& Juselius, K. (1989). The full information maximum likelihood procedure for inference on cointegration-with applications, Department of Economics Discussion paper no. 89-11. University of Copenhagen, Copenhagen.

Johansen, S., \& Juselius, K. (1990). Maximum likelihood estimation and inference on cointegration-with applications to the demand for money. Oxford Bulletin of Economics and statistics, 52(2), 169-210. http://dx.doi.org/10.1111/j.1468-0084.1990.mp52002003.x

Johnson, K. (2008). Food Price Inflation: Explanation and Policy Implications. Working paper, Centre for Geo-economic studies, Council on Foreign Relations, New York.

Kalkuhl, M. (2014). How Strong Do Global Commodity Prices Influence Domestic Food Prices in Developing Countries? A Global Price Transmission and Vulnerability Mapping Analysis. A Global Price Transmission and Vulnerability Mapping Analysis (May 2014). ZEF-Discussion Papers on Development Policy, (191). http://dx.doi.org/10.2139/ssrn.2437443

Kelbore, Z. G. (2013). Transmission of world food prices to domestic market: The Ethiopian case. MPRA Paper No: 49712.

Kwiatkowski, D., Phillips, P. C. B., \& Schmidt, P., \& Shin, Y. (1992). Testing the null hypothesis of stationarity against the alternative of a unit root: how sure are we that economic time series are non stationary? Journal of Econometrics, 54, 159-178. http://dx.doi.org/10.1016/0304-4076(92)90104-Y

Lee, H. H., \& Park, C. Y. (2013). International Transmission of Food Prices and Volatilities: A Panel Analysis. Asian Development Bank Economics Working Paper Series, (373). http://dx.doi.org/10.2139/ssrn.2323056

Lee, S., Lim, J. Y., Lee, H. H., \& Park, C. Y. (2013). Food Prices and Population Health in Developing Countries: An Investigation of the Effects of the Food Crisis Using a Panel Analysis (No. 374). Asian Development Bank.

Lutz, C., Kuiper, W. E., \& Van Tilburg, A. (2007). Maize market liberalisation in Benin: a case of hysteresis. Journal of African Economies, 16(1), 102-133. http://dx.doi.org/10.1093/jae/ejk008

Mahendra Dev. S. (2013). Rising food prices in south Asia a policy frame work to mitigate adverse effects, ESCAP, South and South West Asia Office

Minot, N. (2009). Transmission of world food price changes to African markets and its effect on household welfare. International Food Policy Research Institute (IFPRI).

Minot, N. (2011). Transmission of world food price changes to markets in Sub-Saharan Africa. Washington: International Food Policy Research Institute.

Morisset, J. (1998). Unfair trade? The increasing gap between world and domestic prices in commodity markets during the past 25 years. The World Bank Economic Review, 12(3), 503-526. http://dx.doi.org/10.1093/wber/12.3.503 
Mundlak, Y., \& Larson, D. F. (1992). On the transmission of world agricultural prices. The World Bank economic review, 6(3), 399-422. http://dx.doi.org/10.1093/wber/6.3.399

Myers, R. J. (1992). Time series econometrics and commodity price analysis. Department of Economics The University of Queensland.

Negassa, A., \& Myers, R. J. (2007). Estimating policy effects on spatial market efficiency: An extension to the parity bounds model. American Journal of Agricultural Economics, 89(2), 338-352. http://dx.doi.org/10.1111/j.1467-8276.2007.00979.x

Phillips, P. C., \& Perron, P. (1988). Testing for a unit root in time series regression. Biometrika, 75(2), 335-346. http://dx.doi.org/10.1093/biomet/75.2.335

Quiroz, J. A., \& Soto, R. (1995). International Price Signals in Agricultural Markets: Do Governments Care?. ILADES/Georgetown University.

Rapsomanikis, G. (2011). In A. Prakash (Ed.), Price Transmission and Volatility Spillovers in Food Markets, appeared I Safeguarding Food Security in Volatile Global Markets. Food and Agriculture Organization.

Rapsomanikis, G., Hallam, D., \& Conforti, P. (2006). Market integration and price transmission in selected food and cash crop markets of developing countries: review and applications. In A. Sarris, \& D. Hallam (Ed.), Agricultural Commodity Markets and Trade (pp. 187-217), Edward Elgar, Cheltenham, UK.

Rashid, S. (2011). Inter-commodity price transmission and food price policies: An analysis of Ethiopian Cereals Markets. IFPRI Discussion paper1079, Washington, D.C, International Food Policy Research Institute.

Shawarby, S. A., \& Selim, H. (2012).Are International Food Price Spikes the Source of Egypt's High Inflation? Policy Research Working Paper, (6177).

Stock, J. H., \& Watson, M. W. (1988). Variable trends in economic time series. The Journal of Economic Perspectives, 2(3), 147-174. http://dx.doi.org/10.1257/jep.2.3.147

United Nations ESCAP. (2011). Rising Food Prices and Inflation in the Asia-Pacific region: Causes, Impact and Policy Response. Bangkok

Van Campenhout, B. (2007). Modeling trends in food market integration: Method and an application to Tanzanian maize markets. Food Policy, 32, 112-127. http://dx.doi.org/10.1016/j.foodpol.2006.03.011

Van Duyne, C. (1982). Food prices, expectations, and inflation. American Journal of Agricultural Economics, 64(3), 419-430. http://dx.doi.org/10.2307/1240634

$\mathrm{Wu}, \mathrm{Y}$. (2004). Understanding international food consumption patterns. University of Western Australia, Business School, Economics.

\section{Copyrights}

Copyright for this article is retained by the author(s), with first publication rights granted to the journal.

This is an open-access article distributed under the terms and conditions of the Creative Commons Attribution license (http://creativecommons.org/licenses/by/3.0/). 